\title{
The Effect of Internal Audit on Budget Management of Local Government of Rwanda
}

\author{
Jean Bosco Harelimana ${ }^{1 *}$ \\ ${ }^{1}$ Institut d'Enseignement Superieur de Ruhengeri, Musanze, Rwanda
}

Received: 23 August, 2017; Accepted: 31 August, 2017; Published: 23 September, 2017

*Corresponding author: Jean Bosco Harelimana, Institut d'Enseignement Superieur de Ruhengeri, Musanze, Rwanda. P.O.B. 155

Email: harelijordan@yahoo.fr

\begin{abstract}
This study aimed at investigating the effect of internal audit on budget management of local government of Rwanda taking Musanze District as case study. The problem of failing to consolidate transactions and balances of NBAs in financial statements of local government has still persisted. Many local governments have not been examining efficiently the internal audit in budgeting process and execution and this has consequently led to mismanagement; lack of control and less budget execution from their activities or operations. Moreover to prove the general objective, the results of this study was presented in accordance with specific objectives stated by the researcher such as, to analyze the internal audit functions in local government of Rwanda; to assess budget process and execution in local government in Rwanda and to analyze the relationship between internal audit and budget process and execution in Rwanda. Descriptive research design was adopted for this study using both qualitative and quantitative methods of data collection. The study used a sample of 18 employees of Musanze District office selected purposive sampling techniques from a targeted population of 18 employees from department of finance of Musanze district Office. The study used primary data collected from semi-structured questionnaires. Based on the findings of this study, it was found that asset management; management control and staffing management are well used to enhance good budgeting process and execution in local government as it was indicated by $100 \%$ of respondents. The budget process and execution in local government is based on budget formulation; budget proposal and dialogue, budget monitoring, budget adjusting, budget control and budget reporting $(100 \%)$. As significant level is at $0.01(1 \%)$, the p value of 0.000 (i.e. $0.0 \%$ ) is less than $1 \%$. This leads to confirm that there is significant relationship correlation between internal audit and budget process and execution in Musanze district office. As it was recommended that Musanze District should put more efforts in raising more revenue to supplement the government transfers and smoothen the budget execution.
\end{abstract}

Keywords: Internal Audit, Budget Process, Execution and Local Government.

\section{General Introduction}

The problem of failing to consolidate transactions and balances of Non Budget Agencies (NBAs) in financial statements of local government has still persisted. Many local governments have not been examining efficiently the internal audit in budgeting process and execution and this has consequently led to mismanagement; lack of control and less budget execution from their activities or operations [30].

According to Association of Certified Faud Examiners, the majority of organizations today have created the internal audit department to examine the fraud issues, financial reporting and misappropriation of the organizations assets by ensuring accuracy, objectivity and consistency of the financial statements as a prerequisite in monitoring proper organizational financial performance [4].Hansen \& Kræmmergaard confirm that , accessing the high level of budgeting process and execution is a challenging task for local government [16]. However, these financing constraints tend to be more difficult for some local government to overcome.

The Ministry of Finance only requires Local government to compile a separate report of balances of budget execution for information purposes (as a disclosure note in financial statements) and they are not consolidated in balances reported in financial statements of Local Government [13]. This implies that balances reported in financial statements of Local government do not include amounts from non budget agencies and hence making District financial statements and state consolidated financial statements incomplete. The problem of failing to consolidate transactions and balances of NBAs in financial statements of local government has still persisted [9].

Hawkesworth et al shown that, many local governments have not been examining efficiently the internal audit in budgeting process and execution and this has consequently led to mismanagement; lack of control and less budget execution from their activities or operations [17]. However, there is no evidence of adequate follow up done to verify the accountability reports submitted to Districts by non- budget agencies and to follow up activities reported by non budget agencies. Such follow up should have been done on a regular basis by Internal Audit unit [26]. As a consequence, there is a continued problem of misuse and misappropriation of public funds being perpetuated through non budget agencies.

The question that arises to the researcher therefore, is to make the analysis on the role of internal audit in budgeting process and execution on local government in Rwanda. 
The main objective of this study is to assess the effect of internal audit on budget process and execution of local government in Rwanda. Specific objectives of this study are the following: To analyze the internal audit functions in local government of Rwanda; to assess budget process and execution in local government in Rwanda and to analyze the relationship between internal audit and budget process and execution in Rwanda.

The usefulness of this research is the improvement of the budgeting process and execution based on internal audit system in local government, the results of findings is very useful to the government. The Government and people now know how it can intervene in budgeting process and execution of much internal audit system in local government in Rwanda through its policies and regulations in terms of taxes. The local government is the backbone of development of its citizens through the funds invested from non budget agencies and national badget prepared and issued by MINALOC if were used and reported well so the internal audit must involved in the management of those funds in order to show the accuracy and fair value of report from Local government. The reason why the researcher intends to assess the effect of internal audit in budget process and execution of local government. The local government is great get importance because some suggestions clarifies where they have to improve and how they are supposed to do it in terms of its budget implementation.

\section{Material And Methods}

In conducting this research, the data were obtained from primary and secondary sources. The primary data was collected by use of a structured interview and questionnaires and the secondary data was obtained from different data base including books and Musanze District annual report.

According to Bartlett et al., population is the full set of cases from which a sample is taken. Population of this study is concerned with all staffs (employees) working in Musanze District (Headquarters) whereby 63 district members of staff were considered as the population to study [5].

According to Stumpf \& Kerle, "the sample is to choose a limited number of individuals, of object or events whose observation makes it possible to draw the conclusions applicable to the whole population inside which the choice is made" [35]. This definition relates to the fact of starting from a limited number of elements to draw the conclusions applicable to the unit in which were drawn. Daniel further defined purposive sampling as a type of sampling in which, "particular settings, persons, or events are deliberately selected for the important information they can provide that cannot be gotten as well from other choices [12]. Purposive sampling technique was used to select respondents from different units of the district office and sectors because they were expected to have necessary information with respect to objectives of the study, their availability and their willingness to participate. The questionnaire was administered to the 18 respondents who are related with budget process and execution from employees of Musanze District. Moreover, Secondary data was obtained from many existing documents.

As said by Teubner \& Woods, data processing is concerned with classifying responses into meaningful category called codes; it consists of editing the schedule and coding the responses [37]. The data processing included: editing, coding, and tabulation. Data was cleaned and edited to ensure consistence of responses.

Becker et al. defined data analysis as the process of compiling and study data to provide summaries, description and conclusion [6]. Data analysis is developed to deal with manipulation of the information that was gathered so as to present the evidence.

Regarding this research the researcher was analyze views give finding by respondent through questionnaire .on this, the qualitative technique was be used. All of those were applied in order to find out and assess the relationship between the both variables included in this study. After coding, data were input into the Statistical Package for Social Sciences (SPSS) for analysis. The data were analyzed using the descriptive statistics like percentages in frequency table in Statistical Package for Social Science (SPSS) software version 20.

\section{Results and Discussion}

This chapter presents data gathered from Musanze district office using questionnaires administered, interviews conducted and documentary review. The chapter also presents the analysis of the data with relevant interpretation and from the presented data, conclusion and suggestions were drawn.

\section{Characteristics of Respondents}

This section was considered imperative that the biographical information of sampled respondents. Presented information includes gender, age, education level and years of working experience.

Gender was assessed in this study since gender can affect the level of judgment on a given phenomenon. Hence, the researcher wanted to determine the gender of the respondents and asked to respondents to indicate their gender as depicted in the table below (Table 3.1).

Table 3.1: Distribution of respondents by gender

\begin{tabular}{|l|c|c|c|c|c|}
\hline & & Frequency & Percent & Valid Percent & $\begin{array}{c}\text { Cumulative } \\
\text { Percent }\end{array}$ \\
\hline Valid & Male & 14 & 77.8 & 77.8 & 77.8 \\
\hline & Female & 4 & 22.2 & 22.2 & 100.0 \\
\hline & Total & 18 & 100.0 & 100.0 & \\
\hline \multicolumn{7}{l}{ Source: Primary data, 2016} & & &
\end{tabular}

The (Table 3.1 ) illustrates that $77.8 \%$ of respondents were male whereas $22.2 \%$ of respondents were female. This implies that majority of respondents are males indicating that males are more than female in the sample. However, since the research were not gender sensitive the researcher deduct that the information that is obtained from both male and female will be equally relevant and reliable to answer the stated research questions. This implies that both women and men have adequate information on the budget processing and execution in Musanze District. 
Age of respondents was identified since age would affect the level of judgment of individuals. Here the researcher wanted to know the age distribution of respondents included in the sample. Hence, respondents were requested to indicate their age category as depicted by the table below (Table 3.2).

\begin{tabular}{|c|c|c|c|c|c|}
\hline \multicolumn{5}{|c|}{ Table 3.2: Distribution of respondents by age } \\
\hline & & Frequency & Percent & $\begin{array}{c}\text { Valid } \\
\text { Percent }\end{array}$ & $\begin{array}{c}\text { Cumulative } \\
\text { Percent }\end{array}$ \\
\hline Valid & $\begin{array}{c}\text { 26 and } \\
\text { above }\end{array}$ & 18 & 100.0 & 100.0 & 100.0 \\
\hline Source & & & &
\end{tabular}

Source: Primary data, 2016

Table above depicts that $100 \%$ of respondents were in the age range of 26 years and above. This implies that sampled respondents are distributed in all categories of age and involve young and mature as well as old individuals who are employees of Musanze district. This indicates that the information collected from these individuals covers ideas and opinions of individuals in many different age categories which make it accurate considering its source.

Education level of respondents was assessed in this study since education achievement represents the potential and ability to reflect on a given phenomenon. Hence, respondents were asked to indicate their highest level of education to ensure that selected respondents are knowledgeable about the variables under study. The results are presented in the table below (Table 3.3).

\begin{tabular}{|c|c|c|c|c|c|}
\hline \multicolumn{6}{|c|}{ Table 3.3: Distribution of respondents by education level } \\
\hline & & Frequency & Percent & $\begin{array}{c}\text { Valid } \\
\text { Percent }\end{array}$ & $\begin{array}{c}\text { Cumulative } \\
\text { Percent }\end{array}$ \\
\hline Valid & Certificate & 1 & 5.6 & 5.6 & 5.6 \\
\hline & Diploma & 3 & 16.7 & 16.7 & 22.2 \\
\hline & Degree & 14 & 77.8 & 77.8 & 100.0 \\
\hline & Total & 18 & 100.0 & 100.0 & \\
\hline
\end{tabular}

Source: Primary data, 2016

Table 3.3 illustrates that $77.8 \%$ of respondents acquired masters and bachelors as their highest level of education whereas majority of respondents equivalent to $77.8 \%$ attained university and are masters or bachelors' degree holders in different field of study whereas $16.7 \%$ of respondents have advanced diploma and 5.6 attained Secondary. This implies that majority of sampled respondents have acquired degrees and another portion have diploma in different field of study which makes them able to understand the questions and provide information on the variables under study.

Experience is considered worth an asset for an organization because the long experience that one has in executing the task, the more expertise they accumulated making them better task performers. Here, the researcher wanted to know the period in which they worked for Musanze district. Hence, respondents were asked to indicate the period for which they had served for the institution under study to ensure that sampled employees have adequate information about the functioning of the budgeting process in the District.
Table 3.4 shows the years of service for which respondents worked for Musanze district. Findings in the (Table 3.4) show that $61.1 \%$ of respondents have worked for Musanze District for a period of 5 years and above whereas minority of respondents equivalent to $38.9 \%$ of respondents have worked for the district in a period between 3 to 4 years. This implies that the majority of respondents worked for the district for a considerably long period indicating that they have vast information about the functioning of the budget processing and execution of Musanze District they work for.

Table 3.4 : Distribution of respondents by years of experience

\begin{tabular}{|c|c|c|c|c|c|}
\hline Valid & Frequency & Percent & $\begin{array}{c}\text { Valid } \\
\text { Percent }\end{array}$ & $\begin{array}{c}\text { Cumulative } \\
\text { Percent }\end{array}$ \\
\hline & $\begin{array}{c}\text { 5 years and } \\
\text { above }\end{array}$ & 7 & 38.9 & 38.9 & 38.9 \\
\hline & 11 & 61.1 & 61.1 & 100.0 \\
\hline Total & 18 & 100.0 & 100.0 & \\
\hline
\end{tabular}

Source: Primary data, 2016

\section{Analysis of Respondents' Views on Internal Audit of Budget Process and Execution in Local Government}

Preparation of budgets in an organization is a management function as well as an accounting task. Here, the study wanted to know the budget processing and execution's practices adopted by Musanze district and requested respondents to present their views on different practices and functions. Hence, this section presents the budget processing and execution practices adopted by Musanze district.

Respondents were asked to highlight whether asset management is a systematic approach of maintaining and operating physical assets in Musanze district office. The view of respondents is presented in tables below (Table 3.5).

Table 3.5: Respondents view on whether asset management is a systematic approach of maintaining and operating physical assets

\begin{tabular}{|c|c|c|c|c|c|}
\hline & Frequency & Percent & Valid Percent & $\begin{array}{c}\text { Cumulative } \\
\text { Percent }\end{array}$ \\
\hline Valid & Agree & 11 & 61.1 & 61.1 & 61.1 \\
\hline & $\begin{array}{c}\text { Strongly } \\
\text { Agree }\end{array}$ & 7 & 38.9 & 38.9 & 100.0 \\
\hline & Total & 18 & 100.0 & 100.0 & \\
\hline
\end{tabular}

Source: Primary Data, 2016

According to the (Table 3.5), the greater number about $61.1 \%$ of respondents agreed that asset management is a systematic approach of maintaining and operating physical assets in Musanze District while 38.9\% of all respondents strongly agreed that asset management is a systematic approach of maintaining and operating physical assets in Musanze District. This means that asset management is well used in Musanze District office in order to make a good budget preparation and execution through good practice of internal audit. This is in line with Zhang et al. who stated that asset management is a systematic approach 
of maintaining, upgrading, and operating physical assets cost effectively [38]. Bhamidipati added that it combines engineering principles with sound business practices and economic theory, and it provides tools to facilitate a more organized, logical approach to decision making [7]. Thus, asset management provides a framework for handling both short- and long-range planning.

According to the (Table 3.6), the greater number about 55.6\% of respondents agreed that asset management is a methodology to efficiently and equitable allocate resources among valid and competing goals and objectives in Musanze District while 44.4\% of all respondents strongly agreed that asset management is a methodology to efficiently and equitable allocate resources among valid and competing goals and objectives in Musanze District. This means that asset management is well used in Musanze District office in order to make a good budget preparation and execution through good practice of internal audit. This findings is in line with Pedersen \& Garleanu who stated that asset management is a methodology to efficiently and equitably allocate resources amongst valid and competing goals and objectives [27]. Finally, Bloch \& Bloch, emphasizes the service to the public, which is the end customer of the road agencies and administrations and to him , asset management is a systematic process of maintaining, upgrading and operating assets, combining engineering principles with sound business practice and economic rationale, and providing tools to facilitate a more organized and flexible approach to making the decisions necessary to achieve the public's expectations [8].

Table 3.6: Respondents view on whether asset management is a methodology to efficiently and equitable allocate resources among valid and competing goals and objectives

\begin{tabular}{|l|l|c|c|c|c|}
\hline & & Frequency & Percent & $\begin{array}{l}\text { Valid } \\
\text { Percent }\end{array}$ & $\begin{array}{l}\text { Cumulative } \\
\text { Percent }\end{array}$ \\
\hline Valid & Agree & 10 & 55.6 & 55.6 & 55.6 \\
\hline & $\begin{array}{l}\text { strongly } \\
\text { agree }\end{array}$ & 8 & 44.4 & 44.4 & 100.0 \\
\hline & Total & 18 & 100.0 & 100.0 & \\
\hline
\end{tabular}

Source: Primary Data, 2016

Respondents were asked to highlight whether management control is well applied in Musanze District office. The view of respondents is presented in tables below (Table 3.7).

According to the (Table 3.7) the greater number about 55.6\% of respondents strongly agreed that management control is well applied in Musanze District office while $44.4 \%$ of all respondents strongly agreed that management control is well applied in Musanze District office. This means that management control is well applied in Musanze District office in order to make a good budget preparation and execution through good practice of internal audit.

The findings is in line with Brown who stated that a Management Control System (MCS) is a system which gathers and uses information to evaluate the performance of different organizational resources like human, physical, financial and also the organization as a whole in light of the organizational strategies pursued [10].

Table 3.7: Respondents view on whether management control is well applied in Musanze District office

\begin{tabular}{|c|c|c|c|c|c|}
\hline & Frequency & Percent & $\begin{array}{c}\text { Valid } \\
\text { Percent }\end{array}$ & $\begin{array}{c}\text { Cumulative } \\
\text { Percent }\end{array}$ \\
\hline Valid & Agree & 8 & 44.4 & 44.4 & 44.4 \\
\hline & $\begin{array}{c}\text { Strongly } \\
\text { Agree }\end{array}$ & 10 & 55.6 & 55.6 & 100.0 \\
\hline & Total & 18 & 100.0 & 100.0 & \\
\hline
\end{tabular}

Source: Primary Data, 2016

According to the (Table 3.8), the greater number about $50.0 \%$ of respondents strongly agreed that Musanze district office use formal management control system while $50.0 \%$ of all respondents strongly agreed that Musanze district office use formal management control system. This means that management control is well applied in Musanze District office in order to make a good budget preparation and execution through good practice of internal audit.

The findings is in line with Armesh et al. who stated that management control system influences the behavior of organizational resources to implement organizational strategies [3]. Management control system might be formal or informal.

Table 3.8: Respondents view on whether Musanze district office use formal management control system

\begin{tabular}{|l|c|c|c|c|c|}
\hline & & Frequency & Percent & $\begin{array}{c}\text { Valid } \\
\text { Percent }\end{array}$ & $\begin{array}{c}\text { Cumulative } \\
\text { Percent }\end{array}$ \\
\hline Valid & Agree & 9 & 50.0 & 50.0 & 50.0 \\
\hline & $\begin{array}{c}\text { Strongly } \\
\text { agree }\end{array}$ & 9 & 50.0 & 50.0 & 100.0 \\
\hline & Total & 18 & 100.0 & 100.0 & \\
\hline
\end{tabular}

According to the (Table 3.9), the greater number about 50.0\% of respondents strongly agreed that management control helps Musanze district office to achieve its objectives while $50.0 \%$ of all respondents strongly agreed that management control helps Musanze district office to achieve its objectives in order to make a good budget preparation and execution through good practice of internal audit. Those findings are confirmed by the research done by Raduan et al. that who stated that management control systems are tools to aid management for steering an organization toward its strategic objectives and competitive advantage [29]. Management controls are only one of the tools which managers use in implementing desired strategies. However strategies get implemented through management controls, organizational structure, human resources management and culture [31].

Respondents were asked to highlight whether staff management is well applied in Musanze District office in its internal audit staffing. The view of respondents is presented in tables below (Table 3.10)

According to the (Table 3.10), the greater number about $50.0 \%$ of respondents strongly agreed that Staff management is well applied in Musanze District office in its internal audit 
staffing while $50.0 \%$ of all respondents strongly agreed that Staff management is well applied in Musanze District office in its internal audit staffing in order to make a good budget preparation and execution through good practice of internal audit. This is in the line with Brymer et al. who stated that before hiring or beginning any type of internal audit staffing, the organization must determine its human capital strategy [11].

Table 3.9: Respondents view on whether management control helps Musanze district office to achieve its objectives

\begin{tabular}{|c|c|c|c|c|c|}
\hline & & Frequency & Percent & $\begin{array}{c}\text { Valid } \\
\text { Percent }\end{array}$ & $\begin{array}{c}\text { Cumulative } \\
\text { Percent }\end{array}$ \\
\hline Valid & Agree & 9 & 50.0 & 50.0 & 50.0 \\
\hline & $\begin{array}{c}\text { Strongly } \\
\text { Agree }\end{array}$ & 9 & 50.0 & 50.0 & 100.0 \\
\hline & Total & 18 & 100.0 & 100.0 & \\
\hline
\end{tabular}

Source: Primary Data, 2016

Table 3.10: Staff management is well applied in Musanze District office in its internal audit staffing

\begin{tabular}{|c|c|c|c|c|c|}
\hline & Frequency & Percent & $\begin{array}{c}\text { Valid } \\
\text { Percent }\end{array}$ & $\begin{array}{c}\text { Cumulative } \\
\text { Percent }\end{array}$ \\
\hline Valid & Agree & 9 & 50.0 & 50.0 & 50.0 \\
\hline & $\begin{array}{c}\text { Strongly } \\
\text { agree }\end{array}$ & 9 & 50.0 & 50.0 & 100.0 \\
\hline & Total & 18 & 100.0 & 100.0 & \\
\hline
\end{tabular}

Source: Primary Data, 2016

According to the (Table 3.11), the greater number about $61.1 \%$ of respondents agreed that Staff management is well applied in Musanze District office in its internal audit staffing while 38.9\% of all respondents strongly agreed that staff management is well applied in Musanze District office in its internal audit staffing in order to make a good budget preparation and execution through good practice of internal audit. This is in the line with Hoekstra who stated that the first human capital model is the experienced hire career model [19]. An International Accreditation Forum (IAF) that utilizes this model focuses on hiring or "importing" experienced personnel from within or outside the organization [33]. These functions want to ensure that they have auditors with specialized business knowledge and skills. Internal auditing is seen as a permanent career destination [20].The migration model also focuses on ensuring that the IAF is staffed with individuals Core auditors remain with the IAF for an indefinite period of time. This model employs the IAF as a management training ground. Finally, IAFs that employ the change agent model view the IAF as an integral part of the organization's human resource strategy. "Companies using this model selectively deploy talent through internal audit to create a pipeline of corporate change agents who flow continuously into business units. Here, the migration of talent to line businesses occurs as part of a formal corporate strategy to achieve this objective and is a primary performance metric for internal audit" [2].
Table 3.11: Staff management is well applied in Musanze District office in its internal audit staffing

\begin{tabular}{|c|c|c|c|c|c|}
\hline & Frequency & Percent & $\begin{array}{c}\text { Valid } \\
\text { Percent }\end{array}$ & $\begin{array}{c}\text { Cumulative } \\
\text { Percent }\end{array}$ \\
\hline Valid & Agree & 11 & 61.1 & 61.1 & 61.1 \\
\hline & $\begin{array}{c}\text { Strongly } \\
\text { agree }\end{array}$ & 7 & 38.9 & 38.9 & 100.0 \\
\hline & Total & 18 & 100.0 & 100.0 & \\
\hline
\end{tabular}

Source: Primary Data, 2016

Table 3.12 reveals that the $83.3 \%$ of respondents agreed that internal auditing is seen a permanent career destination in Musanze District office while $16.7 \%$ of all respondents agreed that internal auditing is seen a permanent career destination in Musanze District office. This means that internal auditing is seen a permanent career destination in Musanze District office as it indicated by $100 \%$ of respondents. This is due to the good practice of internal audit. This is in line with Sarens et al. who stated that internal auditing is seen as a permanent career destination [32]. The migration model also focuses on ensuring that the IAF is staffed with individuals who possess skills that are proven to make the IAF a successful part of the organization. While this model is not designed to automatically move personnel from the IAF to management positions, the movement of successful internal auditors into other areas of the organization is seen as a positive sign of the IAF's ability to add value to the organization [28].On the other hand, the strategy implicit in the consulting model's strategy is to recruit auditors into the IAF only to later move these individuals into other organizational functions. Under this model, the IAF consists of a group of consultant auditors and another group of core auditors. Consultants are internal auditors who expect to move to other areas of the organization upon gaining valuable experience within the IAF. Core auditors remain with the IAF for an indefinite period of time [22].

Table 3.12: Respondents' view on internal auditing is seen a permanent career destination in Musanze District office

\begin{tabular}{|c|c|c|c|c|c|}
\hline & & Frequency & Percent & $\begin{array}{c}\text { Valid } \\
\text { Percent }\end{array}$ & $\begin{array}{c}\text { Cumulative } \\
\text { Percent }\end{array}$ \\
\hline Valid & Agree & 15 & 83.3 & 83.3 & 83.3 \\
\hline & $\begin{array}{c}\text { Strongly } \\
\text { agree }\end{array}$ & 3 & 16.7 & 16.7 & 100.0 \\
\hline & Total & 18 & 100.0 & 100.0 & \\
\hline
\end{tabular}

Source: Primary Data, 2016

The respondents view on budget process and execution in Musanze district office. The view of respondents is presented in tables below (Table 3.13).

Table 3.13 reveals that the $61.1 \%$ of respondents strongly agreed that budget process and execution in Musanze district office is well used while $38.9 \%$ of all respondents agreed that budget process and execution in Musanze district office is well used. This is due to the good practice of internal audit. According to Johansson \& Siverbo, budget process refers to the process by which governments create and approve a budget, which is as 
follows: The Financial Service Department prepares worksheets to assist the department head in preparation of department budget estimates; the Administrator calls a meeting of managers and they present and discuss plans for the following year's projected level of activity; the managers can work with the Financial Services, or work alone to prepare an estimate for the departments coming year; the completed budgets are presented by the managers to their Executive Officers for review and approval; Justification of the budget request may be required in writing. In most cases, the manager talks with their administrative officers about budget requirements [21]. Adjustments to the budget submission may be required as a result of this phase in the process.

Table 3.13: Respondents' view on budget process and execution in Musanze district office

\begin{tabular}{|c|c|c|c|c|c|}
\hline & & Frequency & Percent & $\begin{array}{c}\text { Valid } \\
\text { Percent }\end{array}$ & $\begin{array}{c}\text { Cumulative } \\
\text { Percent }\end{array}$ \\
\hline Valid & Agree & 7 & 38.9 & 38.9 & 38.9 \\
\hline & $\begin{array}{c}\text { Strongly } \\
\text { agree }\end{array}$ & 11 & 61.1 & 61.1 & 100.0 \\
\hline & Total & 18 & 100.0 & 100.0 & \\
\hline
\end{tabular}

Source: Primary Data, 2016

Table 3.14 reveals that the $88.9 \%$ of respondents agreed that budget proposals and dialogue is used in budget process and execution in Musanze district office while $11.1 \%$ of all respondents agreed that budget proposals and dialogue is used in budget process and execution in Musanze district office. This means that budget proposals and dialogue is used in budget process and execution in Musanze district office as it indicated by $100 \%$ of respondents. This is due to the good practice of internal audit. This is in line with Higdon \& Topp (2004) who stated that a budget proposal must establish parameters for measuring performance with regard to attaining goals and meeting benchmarks. According to National Priorities Project, measuring performance could be something as simple as monthly sales figures for a small business budget proposal or as complex as the national unemployment rate for the federal government's budget proposal [24]. This standard helps the business predict the likelihood of meeting the goals set forth in the budget proposal. A budget proposal with a high standard for measuring performance may have a lower chance of meeting goals than a budget which requires lower performance numbers [25].

Table 3.14: Respondents' view on budget proposals and dialogue is used in budget process and execution in Musanze district office

\begin{tabular}{|c|c|c|c|c|c|}
\hline & & Frequency & Percent & Valid Percent & $\begin{array}{c}\text { Cumulative } \\
\text { Percent }\end{array}$ \\
\hline Valid & Agree & 2 & 11.1 & 11.1 & 11.1 \\
\hline & $\begin{array}{c}\text { Strongly } \\
\text { Agree }\end{array}$ & 16 & 88.9 & 88.9 & 100.0 \\
\hline & Total & 18 & 100.0 & 100.0 & \\
\hline
\end{tabular}

Source: Primary Data, 2016
Table 3.15 reveals that the $55.6 \%$ of respondents agreed that budget monitoring is used in budget process and execution in Musanze district office while $44.4 \%$ of all respondents agreed that budget monitoring is used in budget process and execution in Musanze district office. This means that budget monitoring is used in budget process and execution in Musanze district office as it indicated by $100 \%$ of respondents. This is due to the good practice of internal audit. According to Sponem \& Lambert, during budget monitoring, to be successful, a budget proposal must quantify a business' objectives and identify how those objectives may be reached [34]. These are confirmed by Susha et al. who said that a budget proposal accomplishes this task by creating benchmarks throughout the year, identifying when goals should be met and the level of performance necessary for those benchmarks to be attainable [36]. These benchmarks should be flexible, allowing the business the ability to shift its goals and performance levels easily to compensate for more financially permissible or adverse market conditions.

Table 3.15: Respondents' view on budget monitoring is used in budget process and execution in Musanze district office

\begin{tabular}{|c|c|c|c|c|c|}
\hline & Frequency & Percent & $\begin{array}{c}\text { Valid } \\
\text { Percent }\end{array}$ & $\begin{array}{c}\text { Cumulative } \\
\text { Percent }\end{array}$ \\
\hline Valid & Agree & 8 & 44.4 & 44.4 & 44.4 \\
\hline & $\begin{array}{c}\text { Strongly } \\
\text { agree }\end{array}$ & 10 & 55.6 & 55.6 & 100.0 \\
\hline & Total & 18 & 100.0 & 100.0 & \\
\hline
\end{tabular}

Source: Primary Data, 2016

Table 3.16 reveals that the $72.2 \%$ of respondents agreed that budget adjusting is used in budget process and execution in Musanze district office while $27.8 \%$ of all respondents agreed that budget adjusting is used in budget process and execution in Musanze district office. This means that budget adjusting is used in budget process and execution in Musanze district office as it indicated by $100 \%$ of respondents. This is due to the good practice of internal audit. This findings are in line with Raghunandan et al. who stated that budgeting adjusting is an extremely individual process which in large part is tied to the fact that we can provide estimates, but we cannot ensure that all students will incur the same cost of living nor that students will arrive with the same financial resources [30]. A hefty part of budgeting comprises an individual's financial resources, such as personal assets and/or financial assistance.

Table 3.16: Respondents' view on budget adjusting is used in budget process and execution in Musanze district office

\begin{tabular}{|c|c|c|c|c|c|}
\hline & Frequency & Percent & $\begin{array}{c}\text { Valid } \\
\text { Percent }\end{array}$ & $\begin{array}{c}\text { Cumulative } \\
\text { Percent }\end{array}$ \\
\hline Valid & Agree & 13 & 72.2 & 72.2 & 72.2 \\
\hline & $\begin{array}{c}\text { Strongly } \\
\text { agree }\end{array}$ & 5 & 27.8 & 27.8 & 100.0 \\
\hline & Total & 18 & 100.0 & 100.0 & \\
\hline
\end{tabular}

Source: Primary Data, 2016 
Table 3.17 reveals that the $55.6 \%$ of respondents agreed that budget control is used in budget process and execution in Musanze district office while $44.4 \%$ of all respondents agreed that budget control is used in budget process and execution in Musanze district office. This means that budget control is used in budget process and execution in Musanze district office as it indicated by $100 \%$ of respondents. This is due to the good practice of internal audit. These are in the line with Abata who confirm that Budgetary control refers to how well managers utilize budgets to monitor and control costs and operations in a given accounting period [1]. In other words, budgetary control is a process for managers to set financial and performance goals with budgets, compare the actual results, and adjust performance.

Table 3.17: Respondents' view on budget control is used in budget process and execution in Musanze district office

\begin{tabular}{|l|c|c|c|c|c|}
\hline Valid & Agree & 8 & 44.4 & 44.4 & 44.4 \\
\hline & $\begin{array}{c}\text { Strongly } \\
\text { Agree }\end{array}$ & 10 & 55.6 & 55.6 & 100.0 \\
\hline & Total & 18 & 100.0 & 100.0 & \\
\hline
\end{tabular}

Source: Primary Data, 2016

Table 3.18 reveals that the $61.1 \%$ of respondents agreed that budget process and execution in Musanze district office while $27.8 \%$ of all respondents agreed that budget process and execution in Musanze district office while $11.1 \%$ of all respondents agreed that budget process and execution in Musanze district office. This means that budget process and execution in Musanze district office as it indicated by $100 \%$ of respondents. This is due to the good practice of internal audit. A budget report is an internal report used by management to compare the estimated, budgeted projections with the actual performance number achieved during a period. In other words, a budget report is designed to compare how close the budgeted performance was to the actual performance during an accounting period [23].

Table 3.18: Respondents' view on budget reporting is used in budget process and execution in Musanze district office

\begin{tabular}{|c|c|c|c|c|c|}
\hline Valid & Not sure & 2 & 11.1 & 11.1 & 11.1 \\
\hline & Agree & 11 & 61.1 & 61.1 & 72.2 \\
\hline & $\begin{array}{c}\text { Strongly } \\
\text { agree }\end{array}$ & 5 & 27.8 & 27.8 & 100.0 \\
\hline & Total & 18 & 100.0 & 100.0 & \\
\hline
\end{tabular}

Source: Primary Data, 2016

Respondents were asked to highlight whether there is a relationship between internal audit and budget process and execution in Musanze district office. Respondents' view is presented in table below (Table 3.19).

Table 3.19 reveals that the $77.8 \%$ of respondents agreed that internal audit contributes to the budget process and execution in Rwanda at high level (80\%-100\%) while $22.2 \%$ of all respondents agreed that internal audit contributes to the budget process and execution in Rwanda at medium level (50\%-79\%). This means that there is a relationship between internal audit and budget process and execution in Musanze district office. This is in the line with Frazer who stated that determine the accuracy and propriety of financial transactions, evaluate financial and operational procedures for adequacy of internal controls and provide advice and guidance on control aspects of new policies, processes systems, verify the existence of assets and ensure that proper safeguards are maintained to protect them from loss, determine the level of compliance with the ministry policies and procedures, and Government laws and regulations, evaluate the accuracy, effectiveness, and efficiency of the electronic information and processing systems, to determine the effectiveness and efficiency of Ministry in accomplishing mission and identify operational opportunities for cost savings and revenue enhancements, coordinate audit efforts with, and provide assistance to, the Audit committee and external auditors finally to investigate fiscal misconduct [15].

Table 3.19: Respondents' view on to what extend internal audit contributes to the budget process and execution in Rwanda

\begin{tabular}{|c|c|c|c|c|c|}
\hline Valid & Frequency & Percent & $\begin{array}{c}\text { Valid } \\
\text { Percent }\end{array}$ & $\begin{array}{c}\text { Cumulative } \\
\text { Percent }\end{array}$ \\
\hline & $\begin{array}{c}\text { Medium } \\
\mathbf{5 0 \% - 7 9 \% )}\end{array}$ & 4 & 22.2 & 22.2 & 22.2 \\
\hline $\begin{array}{c}\text { HIGH } \\
\mathbf{( 8 0 \% - 1 0 0 \% )}\end{array}$ & 14 & 77.8 & 77.8 & 100.0 \\
\hline & Total & 18 & 100.0 & 100.0 & \\
\hline
\end{tabular}

Source: Primary Data, 2016

All responses related to the questions of the reasons of the internal audit were summarized to generate a representative independent variable while all responses related to budget process and execution in Musanze district office were totaled to give the dependent variable.

The variation of spearman Coefficient correlation is between -1 and1. Spearman Coefficient correlation has significance when it is equal or greater than 0.01 . According to the research, the correlation was $0.987(98.7 \%)$ is located in the interval [0.751.00 [categorized as positive and high correlation. As significant level is at $0.01(1 \%)$, the $\mathrm{p}$ value of 0.000 (i.e. $0.0 \%$ ) is less than $1 \%$. This leads to confirm that there is significant relationship correlation between internal audit and budget process and execution in Musanze district office (Table 3.20).

This is in the line stated by Feng et al. that to determine the accuracy and propriety of financial transactions, evaluate financial and operational procedures for adequacy of internal controls and provide advice and guidance on control aspects of new policies, processes systems, verify the existence of assets and ensure that proper safeguards are maintained to protect them from loss, determine the level of compliance with the ministry policies and procedures, and Government laws and regulations, evaluate the accuracy, effectiveness, and efficiency of the electronic information and processing systems, to determine 
the effectiveness and efficiency of Ministry in accomplishing mission and identify operational opportunities for cost savings and revenue enhancements, coordinate audit efforts with, and provide assistance to, the Audit committee and external auditors finally to investigate fiscal misconduct [14].

\begin{tabular}{|c|c|c|c|c|}
\hline \multicolumn{5}{|c|}{ Table 3.20 : Correlations } \\
\hline & & & $\begin{array}{c}\text { Internal } \\
\text { audit }\end{array}$ & $\begin{array}{c}\text { Budget } \\
\text { process } \\
\text { and } \\
\text { execution } \\
\text { in } \\
\text { Musanze } \\
\text { district } \\
\text { office }\end{array}$ \\
\hline \multirow{6}{*}{$\begin{array}{l}\text { Spearman's } \\
\text { rho }\end{array}$} & \multirow{3}{*}{ Internal audit } & $\begin{array}{c}\text { Correlation } \\
\text { Coefficient }\end{array}$ & 1.000 & $.987^{* *}$ \\
\hline & & $\begin{array}{c}\text { Sig. } \\
\text { (2-tailed) }\end{array}$ & . & .000 \\
\hline & & $\mathrm{N}$ & 18 & 18 \\
\hline & \multirow{3}{*}{$\begin{array}{c}\text { Budget } \\
\text { process and } \\
\text { execution } \\
\text { in Musanze } \\
\text { district office }\end{array}$} & $\begin{array}{c}\text { Correlation } \\
\text { Coefficient }\end{array}$ & $.987^{* *}$ & 1.000 \\
\hline & & $\begin{array}{c}\text { Sig. } \\
\text { (2-tailed) }\end{array}$ & .000 & . \\
\hline & & $\mathrm{N}$ & 18 & 18 \\
\hline
\end{tabular}

**. Correlation is significant at the 0.01 level (2-tailed).

Source: Primary data, 2016

\section{Conclusion and Recommendations}

\section{Conclusion}

Based on the findings of this study, the researcher concluded that asset management; management control and staffing management are well used to enhance good budgeting process and execution in local government. The budget process and execution in local government is based on budget formulation; budget proposal and dialogue, budget monitoring, budget adjusting, budget control and budget reporting. As significant level is at $0.01(1 \%)$, the $p$ value of 0.000 (i.e. $0.0 \%$ ) is less than $1 \%$. This leads to confirm that there is significant relationship correlation between internal audit and budget process and execution in Musanze district office.

\section{Recommendations}

Based on the findings and conclusions of this study, the following suggestions are made for the budgeting and budgetary controls of the district to happen in accordance to the regulations and achieve the desired goals and objectives.

- Musanze District should intensify capacity building of its employees in the field of budgeting and budgetary controls ensure that officers keep abreast of the new developments in the field of public finance budgeting.
- Musanze District should improve the participation of all stake holders in budget execution in enhancing the over all budget performance.

- Musanze district should adopt flexible budget which enables the District to adjust possible variances in the course of budget implementation.

- Government of Rwanda should provide its transfers to the Districts and other government institutions at the right time to ensure the timely availability of funds for budget execution and implementation.

- Musanze District should put more efforts in raising more revenue to supplement the government transfers and smoothen the budget execution.

- The researcher suggested that further similar studies need to be conducted in other public institutions in Rwanda in order to assess whether the study could yield similar findings regarding effect of budgeting and budgetary controls on financial performance of public institutions

\section{Acknowledgemnt}

My recognition goes to the Musanze district and all staff members for their help in time of collecting data for this study.

\section{References}

1. Matthew A. Abata. Participative Budgeting and Managerial Performance in the Nigerian Food Products Sector. Global Journal of Contemporary Reasearch Accounting, Auditing and Business Ethics. 2014;1(3):148-167.

2. Abbott LJ, Daugherty B, Parker S, Peters GF. Internal Audit Quality and Financial Reporting Quality: The Joint Importance of Independence and Competence. Journal of Accounting Research. 2016;54(1):3-40. doi:10.1111/1475-679X.12099

3. Armesh H, Salarzehi H, Kord B. Management Control System. Interdisciplinary Journal of Contemporary Research in Business. 2010;2(6):193-206.

4. Association of Certified Faud Examiners. Report to the Nations on Occupational Fraud and Abuse. Global Fraud Study. 2014;15(2):1-80.

5. Bartlett JE, Kotrlik JW, Higgins CC. Organizational Research: Determining Appropriate Sample Size in Survey Research. Information Technology, Learning, and Performance Journal. 2001;9(1):43-50.

6. A. Becker, P. Finger, A. Meyer-Christoffer, B. Rudolf, K. Schamm, U. Schneider, et al. A description of the global land-surface precipitation data products of the Global Precipitation Climatology Centre with sample applications including centennial (trend) analysis from 1901present. Earth System Science Data. 2013;5(1):71-99. doi:10.5194/ essd-5-71-2013

7. Srirama Bhamidipati. Simulation Framework for Asset Management in Climate-change Adaptation of Transportation Infrastructure. In Transportation Research Procedia. 2015;8:17-28. doi:10.1016/j. trpro.2015.06.038

8. Bloch HP. Subject Category 3 - Asset Management. Petrochemical Machinery Insights. 2017;13-22. doi:10.1016/B978-0-12-8092729.00003-7 
9. Douglas A. Brook .Audited Financial Statements in the Federal Government: Intentions, Outcomes and on-Going Challenges for Management and Policy-Making. J. Of Public Budgeting, Accounting \& Financial Management. 2010;22(1):52-83.

10. Brown DA, Malmi T. Management control systems as a packageOpportunities, challenges and research directions. Management Accounting Research. 2008;19(4):287-300.doi. 10.1016/j. mar.2008.09.003

11. Brymer RA, Molloy JC, Gilbert BA. Human capital pipelines: Competitive implications of repeated interorganizational hiring. Journal of Management.2014;40(2):483-508.doi:10.1177/0149206313516797

12.Daniel J. Chapter 5. Choosing the Type of Probability Sampling. Sampling Essentials: Practical Guidelines for Making Sampling Choices. 2012;125-174. doi. 10.4135/9781452272047

13. Daske H, Gebhardt G. International financial reporting standards and experts' perceptions of disclosure quality. Abacus. 2006;42(34):461-498. doi: 10.1111/j.1467-6281.2006.00211.x

14. Feng M, Li C, McVay SE, Skaife H. Does ineffective internal control over financial reporting affect a firm's operations? Evidence from firms' inventory management. The Accounting Review. 2015;90(2):529557. doi: $10.2308 /$ accr-50909

15. Frazer L. The Effect of Internal Control On The Operating Activities Of Small Restaurants. Journal of Business \& Economics. 2012;10(6):361.

16. Hansen LK, Kræmmergaard P. Transforming local government by project portfolio management: Identifying and overcoming control problems. Transforming Government: People, Process and Policy. 2013;7(1):50-75.doi:10.1108/17506161311308160

17. Hawkesworth I, von Trapp L, Nielsen DF. Performance Budgeting in Poland: An OECD Review. OECD Journal on Budgeting. 2011;11(1):757.doi.10.1787/budget-11-5kgg8r57tf34

18. Higdon J, Topp R. How to develop a budget for a research proposal. West J Nurs Res. 2004;26(8):922-929.doi: 10.1177/0193945904269291

19. Hoekstra HA. A career roles model of career development. Journal of Vocational Behavior. 2011;78(2):159-173. doi:10.1016/j. jvb.2010.09.016

20. Jans, M, Alles M, Vasarhelyi M. The case for process mining in auditing: Sources of value added and areas of application. International Journal of Accounting Information Systems. 2013;14(1):1-20.doi. 10.1016/j. accinf.2012.06.015

21. Johansson $\mathrm{T}$, Siverbo $\mathrm{S}$ The appropriateness of tight budget control in public sector organizations facing budget turbulence. Management Accounting Research. 2014;25(4):271-283. doi.10.1016/j. mar.2014.04.001

22. Mat Zain M, Zaman M, Mohamed Z. The Effect of Internal Audit Function Quality and Internal Audit Contribution to External Audit on Audit Fees. International Journal of Auditing. 2015;19(3):134-147. doi:10.1111/ijau.12043

23.MELITSKI J, MANOHARAN A. Performance Measurement, Accountability, and Transparency of Budgets and Financial Reports. Public Administration Quarterly. 2014;38(1):38-70. doi:10.1017/ CB09781107415324.004
24. National Priorities Project. Federal Spending: Where Does the Money Go. 2016.

25. Nisbet RM, Jusup M, Klanjscek T, Pecquerie L. Integrating dynamic energy budget (DEB) theory with traditional bioenergetic models. J Exp Biol. 2012;215(6):892-902.doi: 10.1242/jeb.059675

26. Onumah JM, Krah RY. Barriers and Catalysts to Effective Internal Audit in the Ghanaian Public SectorAccounting in Africa. Research in Accounting in Emerging Economies.2012 (Vol. 12 Part A). doi:10.1108/S1479-3563(2012)000012A012

27. Pedersen, L. H., \& Garleanu, N. B. (2015). Efficiently Inefficient Markets for Assets and Asset Management. NBER Working Paper, XXXIII(2), 81-87. doi: 10.1007/s13398-014-0173-7.2

28. Prawitt DF, Sharp NY, Wood DA. Internal Audit Outsourcing and the Risk of Misleading or Fraudulent Financial Reporting: Did Sarbanes-Oxley Get It Wrong? Contemporary Accounting Research. 2012;29(4):1109-1136. doi: 10.1111/j.1911-3846.2012.01141.x

29. Raduan CR, Jegak U, Haslinda A, Alimin II. Management, Strategic Management Theories and the Linkage with Organizational Competitive Advantage from the Resource-Based View. European Journal of Social Sciences. 2009;11(3):402-418.

30. Raghunandan M, Ramgulam N, Raghunandan-Mohammed K. Examining the Behavioural Aspects of Budgeting with particular emphasis on Public Sector/Service Budgets. International Journal of Business and Social Science. 2012;3(14):110-117.

31. Riccaboni A, Luisa Leone E. Implementing strategies through management control systems: the case of sustainability. International Journal of Productivity and Performance Management. 2010;59(2):130-144. doi. 10.1108/17410401011014221

32. Sarens G, Allegrini M, D’Onza G, Melville R. Are internal auditing practices related to the age of the internal audit function?: Exploratory evidence and directions for future research. Managerial Auditing Journal. 2011;26(1): 51-64. doi.10.1108/02686901111090835

33. Scontrino MP. Review of The IAF handbook of group facilitation: Best practices from the leading organization in facilitation. Personnel Psychology, 2006;59:271-274. doi. 10.1111/j.17446570.2006.00909_16.x

34. Sponem S, Lambert C. Exploring differences in budget characteristics, roles and satisfaction: A configurational approach. Management Accounting Research. 2016;30:47-61. doi.10.1016/j.mar.2015.11.003

35. Stumpf A, Kerle N. Object-oriented mapping of landslides using Random Forests. Remote Sensing of Environment. 2011; 115(10): 2564-2577. doi.10.1016/j.rse.2011.05.013

36. Susha I, Zuiderwijk A, Janssen M, Gronlund, A. Benchmarks for Evaluating the Progress ofOpenDataAdoption.SocialScienceComputer Review. 2015;33(5):613-630. doi.10.1177/0894439314560852

37. Teubner J, Woods L. Data Processing on FPGAs. Synthesis Lectures on Data Management. 2013;1-118. doi.10.2200/ S00514ED1V01Y201306DTM035

38. Zhang X, Arayici Y, Wu S, Abbott C, Aouad G. Integrating BIM and GIS for large scale ( building ) asset management: a critical review. Management. 2009;1-15. 